\title{
Peran Terlipressin pada Penyakit Hati Kronik
}

\author{
Decky Andrea, ${ }^{1}$ Luciana Rotty ${ }^{2}$
}

\author{
${ }^{1}$ Program Pendidikan Dokter Spesialis Ilmu Penyakit Dalam Fakultas Kedokteran Universitas \\ Sam Ratulangi, Manado, Indonesia \\ ${ }^{2}$ Divisi Gastroenterologi-Hepatologi KSM/Bagian Ilmu Penyakit Dalam Fakultas Kedokteran \\ Universitas Sam Ratulangi, Manado, Indonesia \\ Email: decky.andrea@gmail.com
}

\begin{abstract}
Chronic liver disease is a progressive impairment of liver function. It is caused by nonalcoholic fatty liver, viral infection of the liver, excessive alcohol consumption, metabolic diseases such as galactosemia, autoimmune disease, and the influence of chemicals. Complications that are often found are esophageal variceal bleeding, hepatorenal syndrome, and refractory ascites. Terlipressin, which is a vasopressin analogue, is currently widely used in developed countries because it has been shown to improve survival of patients with esophageal varices, hepatorenal syndrome, and refractory ascites. Terlipressin is the current standard therapy for esophageal variceal bleeding in countries where it is available.
\end{abstract}

Keywords: chronic liver disease; terlipressin

\begin{abstract}
Abstrak: Penyakit hati kronis (PHK) adalah gangguan fungsi hati yang terjadi secara progresif. Peyakit hati kronis di sebabkan oleh non-alcoholic fatty liver, infeksi virus pada hati, konsumsi alkohol berlebihan, peyakit metabolik seperti galaktosemia, penyakit autoimun, dan pengaruh bahan kimia. Komplikasi yang sering ditemukan pada PHK ialah perdarahan varises esofagus, sindrom hepatorenal, dan asites refrakter. Terlipressin yang merupakan analog vasopressin saat ini banyak di pakai di negara maju karena terbukti dapat meningkatkan kelangsungan hidup pasien perdarahan varises esofagus, sindrom hepatorenal, dan asites refrakter. Dewasa ini terlipressin telah menjadi terapi standar perdarahan varises esofagus di negara-negara di mana obat ini tersedia.
\end{abstract}

Kata kunci: penyakit hati kronik; terlipressin

\section{Pendahuluan}

Penyakit hati kronis (PHK) adalah gangguan fungsi hati yang terjadi secara progresif. Gangguan fungsi hati mencakup proses peradangan, kerusakan, dan regenerasi parenkim hati yang berkelanjutan yang mengarah pada terjadinya fibrosis dan sirosis. Penyakit hati kronis dapat disebabkan oleh non-alcoholic fatty liver (NAFLD), infeksi virus pada hati, konsumsi alkohol berlebihan, peyakit metabolik seperti galaktosemia, penyakit autoimun, dan pengaruh bahan kimia. ${ }^{1,2}$

Sirosis adalah tahap akhir dari PHK yang mengakibatkan terganggunya arsitek- tur hati, pembentukan nodul, reorganisasi vaskular, neo-angiogenesis, dan pengendapan matriks ekstrasel. Komplikasi yang terjadi pada sirosis yaitu asites refrakter, varises esofagus, sindrom hepatorenal (SHR), ensefalopati hepatikum, sindrom hepatopulmoner, dan gangguan koagulasi. Pada sirosis, kedua hal ini terjadi karena adanya peningkatan tekanan pada vena porta. Salah satu tatalaksana SHR dan perdarahan varises esofagus ialah pemberian obat vasoaktif seperti vasopresin, terlipressin, somatostatin, octreotide, dan vapreotide. ${ }^{3,4}$

Terlipressin adalah analog vasopresin yang memiliki sifat vasoaktif kuat dan telah 
tersedia untuk digunakan di sebagian besar negara selama hampir dua dekade. Terlipressin merupakan pengobatan yang efektif dalam pengelolaan komplikasi penyakit hati kronis dekompensasi. Obat ini menginduksi vasokonstriksi splanknikus sehingga meningkatkan aliran darah ginjal dan memiliki efek menguntungkan pada SHR dan asites refrakter serta pada saat yang bersamaan mengurangi tekanan portal yang berperan dalam mengurangi risiko perdarahan varises esofagus. Selama beberapa waktu terakhir, terlipressin berperan penting dalam pengelolaan SHR dan perdarahan varises esofagus. $^{5}$

Mengingat bahwa pengelolaan PHK masih merupakan tantangan bagi para klinisi maka penulis terdorong untuk membahas secara komprehensif mengenai peran terlipressin dalam kasus PHK terutama yang berkaitan dengan komplikasinya.

\section{Penyakit Hati Kronik}

Penyakit hati kronis adalah serangkaian penyakit yang ditandai dengan penurunan fungsi hati akibat peradangan kronis atau kerusakan hati. Pada tahap yang paling lanjut, PHK sering mengarah pada perkembangan sirosis. Sirosis didefinisikan sebagai perubahan arsitektur hati akibat fibrosis, bekas luka, dan nodul abnormal. Dengan terjadinya sirosis, maka komplikasi yang terjadi yaitu asites refrakter, varises esofagus, sindrom hepatorenal (SHR), ensefalopati hepatikum, sindrom hepatopulmoner, dan gangguan koagulasi. ${ }^{6,7}$

Secara global, 1,5 miliar orang menderita PHK pada tahun 2017, yang paling umum disebabkan oleh NAFLD sebanyak $60 \%$, virus Hepatitis B (VHB) 29\%, virus Hepatitis C (VHC) 9\%, dan penyakit hati akut (PHA) sebanyak 2\%. Di negara-negara Eropa, prevalensi sirosis ialah 833 dari 100.000 (kisaran, 447-1100). Berdasarkan data dari studi Global Burden of Disease, angka kejadian sirosis dan PHK yang distandarisasi oleh usia ialah 20,7 per 100.000 pada tahun 2015 , dan meningkat $13 \%$ dari tahun $2000 .^{7,8}$

Dua jenis virus utama yang menye- babkan penyakit hati kronis, yaitu virus hepatitis B (VHB) dan virus hepatitis C (VHC). Diasumsikan bahwa sekitar 240370 juta orang di dunia terinfeksi VHB secara kronis dan sekitar 150 juta orang terinfeksi VHC. Di Indonesia, VHB menyebabkan sirosis sebesar 40-50\%, VHC sebesar 30-40\% sedangkan penyebab tidak diketahui sebanyak 10-20\%. Alkohol sebagai penyebab sirosis di Indonesia mungkin frekuensinya kecil karena belum terdata dengan baik. ${ }^{6,7}$

Pada PHK, kerusakan yang terjadi pada hati terjadi secara berkelanjutan dan mengakibatkan terjadinya sirosis pada hati. Sirosis dapat menyebabkan hipertensi portal yang dapat menyebabkan banyak komplikasi, seperti asites refrakter, varises esofagus, SHR, ensefalopati hepatikum, sindrom hepatopulmoner, dan gangguan koagulasi. Sirosis dan komplikasinya tidak hanya mengganggu kualitas hidup tetapi juga menurunkan angka harapan hidup. Mengelola pasien dengan sirosis bisa menjadi tantangan serta membutuhkan pendekatan yang terorganisir dan sistematis. ${ }^{9}$

Komplikasi PHK dapat berupa varises esofagus, sindrom hepatorenal, dan asites refrakter.

\section{Varises esofagus}

Hipertensi portal menyebabkan berkembangnya anastomosis portokaval untuk dekompresi sirkulasi portal. Tekanan portal normal ialah berkisar $5-10 \mathrm{mmHg}$ tetapi dengan adanya obstruksi portal, tekanannya bisa mencapai 15-20 mmHg. Seiring waktu, hal ini menyebabkan pleksus vena tersumbat di esofagus distal dan ruptur varises dapat menyebabkan perdarahan. ${ }^{10,11}$

Peningkatan tekanan portal merupakan faktor awal dan paling penting yang mengarah pada pengembangan kolateral sistem portal. Varises gastroesofagus merupakan bagian yang paling umum dan relevan secara klinis dari kolateral ini. Peningkatan tekanan portal sebesar $10-12 \mathrm{mmHg}$ telah ditetapkan untuk perkembangan dan ruptur varises esofagus. ${ }^{11}$

Resistensi vaskular dari pembuluh 
darah kolateral, meskipun lebih rendah dari pada resistensi sistem portal, namun lebih tinggi dari resistensi portal normal. Oleh karena itu, perkembangan kolateral portalsistemik tidak menyebabkan normalisasi tekanan portal, bahkan dalam situasi ekstrim di mana hampir semua aliran portal dialihkan ke sirkulasi sistemik. Pembuluh darah kolateral memiliki lapisan otot polos pembuluh darah, yang dengan kontraksi atau relaksasi, dapat mengubah diameter pembuluh darah. Stimulus vasoaktif yang berbeda mengubah resistensi kolateral, yang mencakup oksida nitrat, stimulasi/blokade p- dan a-adrenergik, vasopresin, endothelin, dan 5-hidroksitriptamin. ${ }^{11}$

\section{Sindrom hepatorenal}

Sindrom hepatorenal merupakan kondisi multiorgan yang memengaruhi ginjal dan hati serta sebagai penyebab cedera ginjal akut yang dapat terjadi pada mereka yang menderita PHK. Asosiasi pertama gagal ginjal pada sirosis diamati pada akhir 1800-an. Pada pertengahan hingga akhir 1900-an, penelitian lebih lanjut mengungkapkan bahwa gagal ginjal dapat terjadi pada sirosis. Hal ini dibuktikan pada pasien SHR dengan gambaran histologik ginjal yang normal disamping tidak adanya proteinuria. $^{12}$

Terdapat beberapa penjelasan patofisiologis yang diajukan tentang mengapa SHR terjadi pada pasien dengan sirosis lanjut dan hipertensi portal. ${ }^{13}$ Hipotesis umum dalam pengembangan SHR ialah penurunan fungsi ginjal yang disebabkan oleh vasodilatasi sistemik yang parah dan vasokonstriksi artreriol ginjal. Peningkatan hipertensi portal dan tegangan geser pada pembuluh darah portal menyebabkan endotel menghasilkan beberapa vasodilatasi lokal seperti nitrik oksida (NO) dan prostanoid. Vasodilator ini bekerja secara lokal pada pembuluh darah splanknikus yang menyebabkan vasodilatasi intens. Selanjutnya terjadi penurunan tekanan darah arteri rerata yang secara efektif menyebabkan aktivasi aksis renin-angiotensinaldosteron (RAA), dan sistem saraf simpatis viseral, untuk meningkatkan curah jantung dan denyut jantung sebagai kompensasi hemodinamik ini. Selain itu, peningkatan pelepasan vasopresin dan sekresi endotelin lokal berkontribusi pada penurunan aliran darah intraglomerular. Pada perkembangan penyakit hati, vasodilatasi splanknikus lebih lanjut dan vasokonstriksi ginjal menyebabkan terjadinya gangguan fungsi ginjal. Aldosteron dan vasopresin menyebabkan retensi natrium dan air, yang selanjutnya dapat memperburuk asites. . $^{13,14}$

Insufisiensi adrenal dilaporkan memengaruhi sekitar $25 \%$ pasien dengan sirosis dekompensasi. Hal ini menyebabkan efek merusak lebih lanjut pada jantung dengan menurunkan reseptor b-adrenergik dan memodulasi efek katekolamin pada kontraksi miokard dan respon vaskular. Efek ini menambah gangguan hemodinamik pasien dengan sirosis dekompensasi. ${ }^{13}$

\section{Asites refrakter}

Asites merupakan salah satu komplikasi yang paling sering ditemukan pada sirosis hepatis, selain ensefalopati hepatik, SHR, dan perdarahan varises esofagus. Sekitar $60 \%$ pasien sirosis akan mengalami asites dalam 10 tahun setelah diagnosis sirosis ditegakkan. Asites refrakter, yang dialami pada 5-10\% pasien dengan asites sirosis, memiliki angka mortalitis yang tinggi. Rerata angka ketahanan hidup 1 tahun diperkirakan sebesar 50\%. Asites refrakter berhubungan dengan komplikasi seperti hiponatremia, peritonitis bakterial spontan (PBS), cedera ginjal akut, dan SHR. ${ }^{13,14}$

Patofisiologi dibalik pembentukan asites didasarkan pada hipotesis vasodilatasi arterial perifer. Namun, inflamasi sistemik yang berkontribusi terhadap vasodilatasi arterial juga berperan dalam patofisiologi komplikasi hipertensi porta, termasuk asites. Menurut hipotesis vasodilatasi arterial perifer, perubahan struktural dan distorsi arsitektur hati akibat sirosis menyebabkan peningkatan resistensi vaskuler intrahepatik disertai peningkatan tegangan pada pembuluh splanknik yang mengakibatkan produksi zat vasoaktif seperti nitrik oksida. ${ }^{13}$

Terjadinya hipertensi porta disebabkan oleh peningkatan aliran splanknik dan 
peningkatan resistensi vaskuler intrahepatik yang mengobstruksi aliran porta. Obstruksi aliran porta menyebabkan zat vasoaktif kemudian masuk ke sirkulasi sistemik melalui shunt portosistemik sehingga terjadi vasodilatasi sistemik yang kemudian menyebabkan underfilling arteri. Dengan menurunnya mean arterial pressure yang memberikan stimulus baroreseptor arterial, terjadi aktivasi RAS dan aktivasi simpatis. Hal ini merupakan respon fisiologis tubuh untuk mengurangi efek vasodilatasi arterial. ${ }^{13,14}$

Aktivasi RAS menyebabkan retensi natrium dan air pada ginjal untuk mempertahankan volume intravaskuler. ${ }^{13,14}$ Saat retensi air dan natrium tidak dapat mengejar derajat vasodilatasi, konsekuensinya ialah penurunan volume darah arterial efektif, berkontribusi pada underfilling arterial. Hal ini kemudian mengakibatkan siklus aktivasi sistem vasokontriktor dan retensi natrium secara terus menerus. Peningkatan tekanan portal pada sirosis lanjut juga disalurkan ke kapiler, menyebakan peningkatan tekanan dan permeabilitas kapiler. Saat sistem limfatik hati tidak mampu mengejar cairan yang terakumulasi di space of Disse, hipertensi porta sinusoid akan mendorong cairan ke kavum peritoneal, mengakibatkan asites. Efek vasokonstriksai dari aktivasi simpatis dan RAS juga menyebabkan vasokonstriksi renal. Bersama dengan gangguan autoregulasi aliran darah ginjal, terjadi hipoperfusi ginjal yang kemudian berakhir pada SHR. ${ }^{15}$

\section{Terlipressin pada Penyakit Hati Kronik Terlipressin}

Terlipressin adalah analog vasopresin yang menjadi populer pada awal 1990-an karena durasi kerja yang lama. Terlipressin diubah menjadi vasopressin lisin dalam sirkulasi setelah residu $N$-triglycyl dipecah oleh peptida endotel. Hal ini menghasilkan pelepasan lambat dari vasopressin lisin vasoaktif. Waktu paruh terlipressin ialah 6 jam sehingga terjadi penurunan tekanan vena portal yang berkepanjangan. ${ }^{14}$

Terlipressin memiliki afinitas terhadap reseptor vasopressin, terutama reseptor V1, yang ditemukan terutama pada otot polos vaskuler di sirkulasi splanknik, namun dapat ditemukan juga pada sirkulasi sistemik, ginjal, aorta, dan jantung. Efek reseptor V1 diperantarai oleh peningkatan kalsium intrasel dari retikulum sarkoplasma atau pelepasan bertahap dari influks kalsium ekstrasel. Peningkatan kalsium ekstrasel ini menimbulkan efek vasokonstriksi. ${ }^{14}$ Terlipressin secara selektif berikatan dengan reseptor V1 dan menurunkan aliran darah splanknik dan tekanan portal dengan vasokontriksi sirkulasi arteri mesenterika Efek tak langsung pada otot polos vaskuler juga diduga diperantarai oleh inhibisi lokal produksi nitrik oksida. ${ }^{2,15}$

Terlipressin meningkatkan tekanan darah arterial dan resistensi vaskuler sistemik, serta menurunkan laju dan curah jantung. Volume darah sentral dapat meningkat atau tidak berubah saat pemberian terlipressin. Perubahan hemodinamik sistemik ini diikuti oleh deaktivasi sistem vasokonstriktor seperti RAS dan sistem saraf simpatis sehingga meningkatkan perfusi dan filtrasi ginjal. Aliran darah hepatik dan vena porta menurun sekitar 30\%. Gradien tekanan vena hepatik (hepatic venous pressure gradient/ HVPG) dan aliran darah azygos menurun sekitar 20\% dalam 30 menit setelah pemberian terlipressin. Penurunan tekanan portal menyebabkan perbaikan sirkulasi hiperdinamik sehingga memperbaiki volume sirkulasi efektif dan tekanan perfusi ginjal. Terlipressin dapat menurunkan tekanan intravariseal sekitar 25\%; semakin tinggi tekanan intravariseal, semakin baik kerja terlipressin. ${ }^{16,17}$

Terlipressin digunakan dalam pengobatan pasien dengan sirosis dan perdarahan varises esofagus dan pasien dengan SHR dan asites refrakter yang merupakan komplikasi yang paling ditakuti pada sirosis. Dalam beberapa dekade terakhir, terdapat penurunan angka kejadian varises esofagus dari $40 \%$ menjadi $15 \%$. Hal ini bertepatan dengan pengenalan modalitas pengobatan vasoaktif seperti terlipressin. Terlipressin diperkenalkan beberapa dekade yang lalu sebagai alternatif vasopressin, dan jarang 
digunakan pada sirosis karena profil keamanannya belum terbukti namun terlipressin sekarang menjadi terapi standar perdarahan varises esofagus di negaranegara di mana obat ini tersedia, karena merupakan satu-satunya obat vasoaktif yang meningkatkan kelangsungan hidup. ${ }^{15}$

\section{Terlipressin pada perdarahan varises esofagus}

Dalam meta-analisis Cochrane dari tujuh uji coba terkontrol plasebo, terlipressin terbukti mengurangi kegagalan untuk mengontrol perdarahan $(\mathrm{RR}=0,66,95 \% \mathrm{CI}$ 0,55 hingga 0,93 ) dan juga untuk meningkatkan kelangsungan hidup $(\mathrm{RR}=0,66,95 \%$ CI 0,49 hingga 0,88 ). Dalam meta-analisis yang sama, tidak terdapat perbedaan antara terlipressin dengan vasopressin, tamponade balon, atau terapi endoskopi dalam kegagalan untuk mengontrol perdarahan atau kelangsungan hidup. ${ }^{16,17}$

Beberapa penelitian yang membandingkan plasebo dengan terlipressin menjelaskan terdapat penurunan angka kematian yang bermakna dengan pemberian terlipressin. Obat ini dapat menghentikan perdarahan yang tidak terkontrol. Semua uji klinis menunjukkan tingkat transfusi yang lebih rendah pada kelompok terlipressin dibandingkan plasebo. Tidak terdapat penelitian yang melaporkan data tentang lama rawat inap di rumah sakit. ${ }^{18,19}$

Tamponade balon (balloon tamponade) sangat efektif dalam mengontrol perdarahan akut pada $90 \%$ pasien meskipun sekitar $50 \%$ terjadi perdarahan ulang saat balon dikempiskan. Namun, hal ini terkait dengan komplikasi serius seperti ulserasi esofagus dan pneumonia aspirasi pada hingga $20 \%$ pasien. Meskipun demikian, prosedur ini merupakan pengobatan yang menyelamatkan jiwa dalam kasus perdarahan varises besar yang tidak terkontrol. Terdapat dua penelitian yang membandingkan efektivitas terlipressin dengan tamponade balon, dan menunjukkan tidak ada perbedaan bermakna dalam parameter luaran. ${ }^{20,21}$ Pada penelitian meta-analisis yang dilakukan oleh Zhou et $\mathrm{al}^{22}$ dijelaskan bahwa penggunaan terlipressin menurunkan risiko perdarahan ulang selama 30 hari dan juga menurunkan kebutuhan akan transfusi darah apabila dibandingkan dengan tamponade balon.

Menurut meta-analisis yang dilakukan Zhou et $\mathrm{al}^{22}$ terdapat penurunan dalam risiko komplikasi pada kelompok yang diberikan terlipressin dibandingkan vasopressin, namun indikator lain seperti risiko perdarahan ulang dan kebutuhan transfusi tidak terdapat perbedaan bermakna.

\section{Terlipressin pada sindrom hepatorenal}

Penelitian pertama terkait terlipressin untuk SHR dipublikasi oleh New Delhi Group pada tahun 2003. Pada penelitian ini, grup $A(n=12)$ diberikan $1 \mathrm{mg}$ terlipressin BD dan Grup B $(n=12)$ menerima plasebo. Kedua kelompok juga menerima dopamin selama 24-48 jam pertama setelah pendaftaran. Kelompok terlipressin mencapai penurunan kadar kreatinin serum yang bermakna dibandingkan plasebo pada hari ke- $8 .^{16}$

Penelitian yang lebih besar kemudian dilakukan di Italia, mencakup luaran sekunder untuk menentukan manfaat terlipressin pada kelangsungan hidup jangka menengah dan panjang. Grup A ( $\mathrm{n}=26)$ menerima $1 \mathrm{mg}$ terlipressin selama lima hari dan kemudian $0,5 \mathrm{mg}$ selama 14 hari tambahan dalam hubungannya dengan albumin intravena (IV). Grup B $(n=26)$ menerima infus albumin IV saja. Kedua kelompok diikuti selama tiga bulan dan jika respon awal tercapai, pengobatan ulang dengan rejimen yang sama diperbolehkan bila terjadi SHR. Kelangsungan hidup lebih besar didapatkan pada kelompok yang diobati dengan terlipressin $(p<0,05)$ dan pasien di Grup A lebih mungkin untuk mencapai perbaikan SHR (kadar kreatinin serum $<133 \mu \mathrm{mol} / \mathrm{L}$ ) dibandingkan kelompok $\mathrm{B}(\mathrm{p}<0,05) .{ }^{17}$

Penelitian multisenter yang lebih besar dilakukan di Amerika Serikat pada tahun 2008. Dalam penelitian ini, kelompok yang diberikan terlipressin awalnya diobati dengan $1 \mathrm{mg}$ QID yang ditingkatkan pada hari ke-3 menjadi $2 \mathrm{mg}$ QID jika kadar kreatinin serum tidak turun setidaknya 30\% dari nilai awal. Keberhasilan pengobatan dicapai oleh 14/56 (25\%) pasien dalam kelompok terlipressin dan 7/56 (12,5\%) 
pasien dalam kelompok kontrol, namun perbedaan ini tidak bermakna $(\mathrm{p}=0,093)$. Dengan menilai luaran sebagai penurunan kadar kreatinin serum menjadi $<133 \mu \mathrm{mol} / \mathrm{L}$, kelompok terlipressin mencapai luaran yang lebih unggul dibandingkan dengan kelompok kontrol $(\mathrm{p}<0,05)$. Namun pada penelitian ini, tidak didapatkan manfaat kelangsungan hidup hingga hari ke-180 $(\mathrm{p}>0,05) .{ }^{18}$

Terlipressin juga telah terbukti lebih unggul dibandingkan terapi alternatif untuk SHR yang biasa digunakan di Amerika Utara. Cavallin et $\mathrm{al}^{23}$ melakukan random control trial (RCT) prospektif yang membandingkan terapi terlipressin dengan kombinasi midodrine dan ocreotide, dan kedua kelompok menerima infus albumin harian. Terdapat 49 pasien SHR yang sesuai dengan kriteria diagnostik diacak untuk menerima terlipressin atau ocreotide/ midodrine. Kelompok terlipressin $(n=27)$ dimulai dengan $3 \mathrm{mg}$ setiap hari yang diberikan selama 24 jam, dan dapat ditingkatkan menjadi dosis maksimal $12 \mathrm{mg}$ /hari sedangkan ocreotide/midodrine $(n=22)$ diberikan masing-masing $100 \mathrm{mcg} / 7,5 \mathrm{mg}$ yang dapat ditingkatkan hingga dosis maksimal menjadi $200 \mathrm{mcg} / 12,5 \mathrm{mg}$. Terapi ini dilanjutkan selama 24 jam tambahan setelah perbaikan SHR (didefinisikan sebagai kadar kreatinin $<133 \mathrm{mmol} / \mathrm{L}$ ) atau total durasi 14 hari. Penelitian ini menyimpulkan bahwa perbaikan SHR dicapai pada 55,8\% kelompok terlipressin dibandingkan dengan hanya $4,8 \%$ pada kelompok ocreotide/ midodrine $(\mathrm{p}<0,001) .{ }^{19,23}$

Penelitian oleh Sharma et $\mathrm{al}^{24}$ mencakup 40 pasien dengan SHR dan kadar kreatinin $>221 \mu \mathrm{mol} / \mathrm{L}$. Semua pasien menjalani ekspansi volume dengan albumin 60 gram/ hari selama dua hari berturut-turut dan jika urine output (UO) tetap <600 $\mathrm{ml} /$ hari atau kadar kreatinin serum $>133$ $\mu \mathrm{mol} / \mathrm{L}$ mereka diacak untuk pengobatan dengan terlipressin atau nor-adrenalin. Grup A $(n=20)$ dimulai dengan NA $0,5 \mathrm{mg} / \mathrm{jam}$ dengan target untuk meningkatkan tekanan darah sistolik (TDS) sebesar $10 \mathrm{mmHg}$ dan UO menjadi $>50 \mathrm{ml} /$ jam. Jika tidak tercapai pada 4 jam, NA ditingkatkan $0,5 \mathrm{mg} / \mathrm{jam}$ menjadi maksimum $3 \mathrm{mg} / \mathrm{jam}$. Grup B $(\mathrm{n}=20)$ dimulai dengan terlipressin $0,5 \mathrm{mg}$ QID dan dosis ditingkatkan 0,5 mg QID jika kadar kreatinin serum tidak mengalami penurunan lebih dari $88 \mu \mathrm{mol} / \mathrm{L}$ selama periode tiga hari. Kedua kelompok menunjukkan peningkatan yang bermakna secara statistik pada kadar kreatinin dan natrium serum, klirens kreatinin, keluaran urin rerata dan mean arterial pressure (MAP) rerata $(p<0,05)$. Selain itu tidak terdapat perbedaan bermakna antar kelompok dalam parameter ini. Juga tidak terdapat perbedaan dalam kelangsungan hidup antara kedua kelompok (kelompok A 55\% vs kelompok B 55\% $\mathrm{p}=0,798)$.

\section{Terlipressin pada asites refrakter}

Pandey et $\mathrm{al}^{25}$ melaporkan bahwa penggunaan infus furosemide perlahan dengan albumin disertai atau tanpa terlipressin dan dipantau secara ketat, aman dilakukan dan efektif sebagai tatalaksana asites besar dan menurunkan kebutuhan parasentesis volume besar. Pasien sirosis dengan asites refrakter yang telah menjalani parasentesis volume besar berkali-kali dalam tiga bulan terakhir diberikan infus furosemid $2 \mathrm{mg} / \mathrm{jam}$ dan albumin 2 gram /jam, kemudian diberikan terlipressin $4 \mathrm{mg}$ / 12 jam. Dari 70 pasien sirosis, 19 pasien hanya diberikan infus albumin dan furosemide sedangkan 51 pasien lainnnya mendapat tambahan infus terlipressin. Respon terapi didapatkan pada semua pasien dengan periode median $7,4 \pm 2,5$ hari, kreatinin pasca terapi 0,94 $\pm 0,43$ (baseline 1,42 $\pm 1,05$ ), natrium serum pasca terapi $133,96 \pm 5,45$ (baseline 129,28 $\pm 7,5$ ), natrium urin maksimum 171,24 $\pm 61,35$ (baseline 17,2 $\pm 5,86$ ), natrium urin saat pulang $86,4 \pm 19,56$, urine output maksimum 2972,08 $\pm 803,6$ (baseline $642,7 \pm 185,3)$, dan albumin serum baseline $2,5 \pm 0,5$.

Terlipressin juga diketahui meningkatkan glomerular filtration rate (GFR), eksresi natrium urin, dan menahan efek vasodilatasi dan sistem antinatiuretik pada sirosis dengan asites. ${ }^{20}$ Penelitian Fimani et $\mathrm{al}^{26}$ terdiri dari 26 pasien sirosis dengan 
asites refrakter tanpa SHR melaporkan peningkatan eksresi natrium urin dan kontrol asites dengan pemberian terlipressin. Terlipressin diberikan 0,5-1 $\mathrm{mg}$ QID selama tiga minggu. Pencapaian $61 \%$ pasien berhasil mengkontrol asites, yang didefinisikan dengan peningkatan empat kali lipat ekskresi natrium urin disertai perbaikan derajat asites, penurunan berat badan, dan $10 \%$ penurunan lingkar perut. Terdapat $15 \%$ pasien yang melaporkan efek samping berupa nyeri abdomen dan diare. Penelitian lain yang terdiri dari 5 pasien dengan asites refrakter melaporkan penurunan bermakna pada jumlah dan volume parasentesis dengan infus terlipressin selama empat minggu. Terlipressin juga meningkatkan MAP, urine output 24 jam, dan kontrol asites. ${ }^{26}$ Terlipressin juga menyebabkan penurunan kreatinin serum pada pasien dengan asites refrakter dan cedera ginjal akut. Bai et al ${ }^{27}$ juga melaporkan hal serupa dimana terlipressin secara bermakna meningkatkan GFR, kreatinin serum, aliran darah ginjal, natrium urin, dan urine output, namun tidak memengaruhi hemodinamik pada pasien sirosis dengan asites refrakter.

\section{Keamanan terlipressin}

Terlipressin dikaitkan dengan beberapa efek samping, termasuk kram perut dan diare yang terjadi pada sekitar $20 \%$. Penilaian efek samping ini mungkin sulit, karena banyak pasien menerima laktulosa setelah mengalami ensefalopati hepatik. Efek samping kardiovaskular terjadi pada sekitar 6\%-40\% pasien. Terlipressin harus dihentikan segera atau dosis dikurangi jika terjadi komplikasi. Nekrosis kulit yang berat dilaporkan pernah terjadi dan pemberian perifer vasopressin infus dosis rendah harus dicegah. Vasopressin mengaktifkan reseptor V2 pada sel endotel yang menyebabkan pelepasan faktor von Willebrand, yang meningkatkan agregasi platelet dan risiko trombosis. Hiponatremia, anafilaksis, bronkospasme, dan iskemia saluran cerna telah dilaporkan terjadi. Namun, penggunaan terlipressin pada pasien sirosis untuk memperbaiki SHR sangat aman. Selain itu karena biasanya disertai pemberian albumin, pasien juga harus dievaluasi dengan cermat selama pengobatan untuk pengenalan dini tanda-tanda kelebihan beban sirkulasi. Pasien harus diberitahu tentang potensi efek samping sebelum memulai terapi terlipressin dan inform consent harus diberikan. ${ }^{28,29}$

\section{Simpulan}

Komplikasi sirosis hepatis yang meningkatkan angka morbiditas dan mortalitas ialah varises esofagus, sindrom hepatorenal dan asites refrakter. Salah satu pengobatan yang dapat diberikan dan merupakan terapi lini pertama ialah terlipressin. Dibandingkan pengobatan lain, pemberian terlipressin memiliki kelebihan namun penggunaan obat ini juga harus dipantau karena memiliki beberapa efek samping. Terlipressin harus dihentikan segera atau dosis dikurangi jika terjadi komplikasi.

\section{Konflik Kepentingan}

Penulis menyatakan tidak terdapat konflik kepentingan dalam studi ini.

\section{DAFTAR PUSTAKA}

1. Thalheimer U, Triantos C, Goulis J, Burroughs AK. Management of varices in cirrhosis. Expert Opin Pharmacother. 2017;12(5): 721-735. Doi:10.1517/14656566.2011. 537258

2. Sarin SK, Sharma P. Terlipressin: an asset for hepatologists! Hepatology. 2011;54(2): 724-28. Doi:10.1002/hep.24519

3. Sharma A NS. Chronic liver disease. [Updated 2020 Feb 28]. In: StatPearls [Internet]. StatPearls Publishing; 2020. [cited 2021 March 14]. Available from: https://www.ncbi.nlm.nih.gov/books/N BK554597/

4. Schuppan D, Afdhal NH. Liver cirrhosis. Lancet. 2008;371(9615):838-51. Doi:10.1016/S0140-6736(08)60383-9

5. Papaluca T, Gow P. Terlipressin: current and emerging indications in chronic liver disease. J Gastroenterol Hepatol. 2018; 33(3):591-98. Doi:10.1111/jgh.14009

6. Nurdjanah S. Sirosis Hati. In: Setiati S, Alwi I, Sudoyo AW, Simadibrata M, Setiyohadi B, Syam AF, editors. Buku Ajar Ilmu Penyakit Dalam (6th ed). Jakarta: 
Interna Publishing, 2014; p. 445-8.

7. Kasper D, Fauci A, Hauser S, Longo D, Jameson JL, Loscalzo J, editors. Harrison's Gastroenterology and Hepatology (3rd ed). New York: McGrawHill, 2019.

8. Hope AA, Morrison RS. What Is the clinical course of advanced liver disease and what symptoms are associated with it? In: Evidence-Based Practice of Palliative Medicine. Elsevier Inc., 2012; p. 300-7. Doi:10.1016/B978-1-43773796-7.00053-7

9. Ladep NG, Akbar SMF, Al Mahtab M. Global epidemiology of chronic liver disease. In: Clinical Epidemiology of Chronic Liver Diseases. Springer International Publishing, 2018; p. 41-55. Doi:10. 1007/978-3-319-94355-8_5

10. Moon AM, Webb GJ, Aloman C, Armstrong MJ, Cargill T, Dhanasekaran R, et al. High mortality rates for SARS-CoV-2 infection in patients with pre-existing chronic liver disease and cirrhosis: Preliminary results from an international registry. J Hepatol. 2020;73(3): 705-8. Doi:10.1016/j.jhep.2020.05.013

11. Nusrat S, Khan MS, Fazili J, Madhoun MF. Cirrhosis and its complications: evidence based treatment. World $\mathbf{J}$ Gastroenterol. 2014;20(18):5442-60. Doi:10.3748/wjg.v20.i18.5442

12. Meseeha M, Attia M. Esophageal Varices. StatPearls. Published August 10, 2020. [cited 2021 Jan 17]. Available from: https://www.ncbi.nlm.nih.gov/books/N BK448078/

13. Berzigotti A, Escorsell A, Bosch J. Pathophysiology of variceal bleeding in cirrhotics. Ann Gastroenterol. [cited 2021 March 14]. Available from: http://www.annalsgastro.gr/index.php/a nnalsgastro/article/view/74/65

14. Ranasinghe IR, Sharma B, Bashir K. Hepatorenal sSyndrome. StatPearls Publishing; 2021. [cited 2021 March 14]. Available from: http://www.ncbi. nlm.nih.gov/pubmed/28613606

15. Amin AA, Alabsawy EI, Jalan R, Davenport A. Epidemiology, pathophysiology, and management of hepatorenal syndrome. Semin Nephrol. 2019;39(1):17-30. Doi:10.1016/j.semnephrol.2018.10.002

16. Simonetto DA, Gines P, Kamath PS.
Hepatorenal syndrome: pathophysiology, diagnosis, and management. BMJ. 2020;370:m2687. Doi:10.1136/bmj.m 2687

17. Adebayo D, Neong SF, Wong F. Refractory Ascites in Liver Cirrhosis. Am J Gastroenterol. 2019;114(1):40-7. Doi: 10.1038/s41395-018-0185-6

18. Kulkarni AV, Arab JP, Prekumar M, Benitez C, Ravikumar ST, Kumar P, et al. Terlipressin has stood the test of time: vlinical overview in 2020 and future perspectives. Liver Int. 2020;40(12): 2888-905.

19. Kam PCA, Williams S, Yoong FFY. Vasopressin and terlipressin: Pharmacology and its clinical relevance. Anaesthesia. 2004;59(10):993-1001.

20. Krag A, Borup T, Møller S, Bendtsen F. Efficacy and safety of terlipressin in cirrhotic patients with variceal bleeding or hepatorenal syndrome. Adv Ther. 2008;25(11):1105-40. Doi:10.1007/s 12325-008-0118-7

21. Solanki P, Chawla A, Garg R, Gupta R, Jain M, Sarin SK. Beneficial effects of terlipressin in hepatorenal syndrome: a prospective, randomized placebocontrolled clinical trial. J Gastroenterol Hepatol. 2003;18(2):152-6. Doi:10. 1046/j.1440-1746.2003.02934.x

22. Zhou X, Tripathi D, Song T, Shao L, Han B, Zhu J, et al. Terlipressin for the treatment of acute variceal bleeding: A systematic review and meta-analysis of randomized controlled trials. Med (United States). 2018;97(48):e13437. Doi:10.1097/MD.0000000000013437

23. Cavallin M, Kamath PS, Merli M, Fasolato S, Toniutto P, Salerno F, et al. Terlipressin plus albumin versus midodrine and octreotide plus albumin in the treatment of hepatorenal syndrome: a randomized trial. Hepatology. 2015;62(2):567-574. Doi:10.1002/hep.27709

24. Sharma P, Kumar A, Shrama BC, Sarin SK. An open label, pilot, randomized controlled trial of noradrenaline versus terlipressin in the treatment of type 1 hepatorenal syndrome and predictors of response. Am J Gastroenterol. 2008; 103(7):1689-1697. Doi:10.1111/j.15720241.2008.01828.x

25. Pandey G, Durgappa M, Kumar A, Singh A, Nehra A, Mishra P, et al. Slow con- 
32 Medical Scope Journal (MSJ), Volume 3, Nomor 1, Juli-Desember 2021, hlm. 24-32

tinuous albumin infusion with furosemide with or without terlipressin in cirrhotic patients with refractory ascites. J Hepatol. 2018;68(1):S742. Doi:10 $.1016 / \mathrm{S} 0168-8278(18) 31746-\mathrm{X}$

26. Fimiani B, Guardia DD, Puoti C, D'Adamo G, Cioffi O, Pagano A, et al. The use of terlipressin in cirrhotic patients with refractory ascites and normal renal function: a multicentric study. Eur J Intern Med. 2011;22(6):587-90.

27. Bai Z, An Y, Guo X, Teschke R, MendezSanchez N, Li H, et al. Role of terlipressin in cirrhotic patients with ascites and without hepatorenal syndrome: a systematic review of current evidence. Canadian Journal of Gastroenterology and Hepatology. 2020;2020 Article ID 5106958.

28. Saner FH, Canbay A, Gerken G, Broelsch CE. Pharmacology, clinical efficacy and safety of terlipressin in esophageal varices bleeding, septic shock and hepatorenal syndrome. Expert Rev Gastroenterol Hepatol. 2007;1(2):20717. Doi:10.1586/17474124.1.2.207

29. Tripathi D, Stanley AJ, Hayes PC, Patch D, Milson C, Mehrzad $\mathrm{H}$, et al. UK guidelines on the management of variceal haemorrhage in cirrhotic patients. Gut. 2015;64(11):1680-1704. Doi:10.1136/gutjnl-2015-309262 